UDC 544.6.018.47-036.5

M.M. Zhyhailo ${ }^{a}$, O.I. Demchyna ${ }^{a}$, I.Yu. Yevchuk ${ }^{a}$, B.I. Rachiy ${ }^{b}$, V.V. Kochubey ${ }^{c}$

\title{
PREPARATION AND CHARACTERIZATION OF UV-CURABLE CROSS-LINKED ORGANIC-INORGANIC MEMBRANES
}

\author{
a Department of Physical Chemistry of Fossil Fuels of the L.M. Lytvynenko Institute of Physical-Organic \\ Chemistry and Coal Chemistry of the National Academy of Sciences of Ukraine, Lviv, Ukraine \\ ${ }^{b}$ Vasyl Stefanyk Precarpathian National University, Ivano-Frankivsk, Ukraine \\ c Lviv Polytechnic National University, Lviv, Ukraine
}

\begin{abstract}
The synthesis of a series of hybrid polymer-inorganic membranes based on acrylic monomers (acrylic acid, acrylonitrile and 3-sulfopropylacrylate potassium salt) and sol-gel system 3methacryloxypropyltrimethoxysilane-ethanol-water with various ratios organic/inorganic is reported in this paper. The synthetic procedure includes UV-initiated polymerization of monomers in the presence of photoinitiator and cross-linker and sol-gel process in situ. A high content of gel fraction ( $>95 \%)$ indicates the successful synthesis and formation of cross-linked polymer-inorganic structures insoluble in organic solvents and water. Investigations performed by means of impedance spectroscopy showed high proton conductivity of membranes $\left(10^{-4}-10^{-2} \mathrm{~S} \mathrm{~cm}^{-1}\right)$ and its dependence on temperature and material composition. The prepared membranes have relatively good chemical stability in the time interval of testing and high ion-exchange capacity $\left(1.12-1.68 \mathrm{meq}^{-1}\right)$. Thermogravimetric study showed the influence of the content of inorganic component on the increase of thermal stability of the membranes. Consequently, taking into account the complex of the characteristics, the synthesized organic-inorganic materials is a potential candidate for DMFC application.
\end{abstract}

Keywords: proton conductive membrane; organic-inorganic material; UV curing; sol-gel process; acrylic acid; acrylonitrile; 3-sulfopropylacrylate potassium salt; 3-methacryloxypropyltrimethoxysilane.

DOI: $10.32434 / 0321-4095-2019-126-5-34-41$

\section{Introduction}

The widespread use of batteries has created many environmental concerns, such as toxic metal pollution. Battery manufacture consumes resources and often involves hazardous chemicals. Used batteries also contribute to electronic waste. Environmental issues related with atmospheric pollution, green house effects and global warming have to be solved. Therefore, researchers are challenged to develop new types of efficient environmentally-benign energy devices [1].

Nowadays, the interest in the fuel cell technology has increased significantly. In contrast to the environmental and efficiency limitations associated with thermal processes that are commonly used for producing energy from fossil fuels, fuel cells have potentially higher efficiencies with absence of gaseous pollutants, such as sulfur dioxide and various nitrogen oxides, along with striking simplicity, the absence of moving parts and quick start up and shut down time [2,3]. The possible applications of this technology involve stationary power production, transportation, portable systems to supply portable electric equipment, such as notebooks, cellular phone and video cameras [4].

Hydrogen is the best fuel in terms of energy conversion; however, its production, storage and distribution is connected with some problems. No efficient and practical method of storing hydrogen currently exists.

Recently direct alcohol fuel cells (DAFC) using alcohol (usually methanol or ethanol) as a fuel are considered as promising energy conversion devices owing to their high energy efficiency, low emission, stable and simple operating conditions at a relatively low temperature, no requirement of fuel reforming

(C) M.M. Zhyhailo, O.I. Demchyna, I.Yu. Yevchuk, B.I. Rachiy, V.V. Kochubey, 2019

M.M. Zhyhailo, O.I. Demchyna, I.Yu. Yevchuk, B.I. Rachiy, V.V. Kochubey 
process and environmentally friendly nature [5]. Alcohols are liquids at ambient conditions making them easy to handle, store and transport. Moreover, because alcohols are liquid, they also have higher volumetric energy density than $\mathrm{H}_{2}$ fuel at room temperature and pressure. Therefore, DAFCs are more compact without the need for a heavy and bulky external fuel reformer. In addition, some alcohols are renewable and have low toxicity [6].

To improve the performance of DAFC, especially to reduce methanol crossover, considerable efforts have been devoted to modify Nafion (the state-of-the-art membrane) or to develop alternative new nonperfluorinated PEM materials. Other types of membranes utilized in DAFCs include polybenzimidazole (PBI), poly(vinyl alcohol) (PVA) and sulfonated poly(ether ether ketone) (SPEEK) membranes. Nevertheless, their proton conductivity is lower as compared to Nafion.

Organic-inorganic composites constitute an important research field due to their advantages in improving mechanical and thermal properties as well as proton conductivity. The formation of selfcrosslinked silica network (usually as a result of solgel process of precursors) not only can suppress the swelling and methanol diffusion but also can improve the stability, water retention and mechanical strength of PEM. Therefore, crosslinking techniques have received extensive attention for PEMs used in DAFCs. The authors [7] obtained a series of the self-crosslinked organic-inorganic proton conductive membranes by two-step process: first, siliconcontaining sulfonated polystyrene/acrylate nanoparticle latex was prepared via emulsion copolymerization of a variety of monomers: styrene (St), butyl acrylate (BA), methacrylic acid, triethylene glycol dimethacrylate and 2-hydroxyethyl methacrylate with 4-styrene sulfonic acid sodium salt hydrate $(99 \%)$ at the presence of vinyltriethoxysilicone; second, the synthesized latex was poured onto a clean surface of glass and dried in a vacuum oven to form a membrane. The hydrolysis and condensation reactions of $\mathrm{Si}(\mathrm{OR})_{3}$ groups of precursor (vinyltriethoxysilicone) lead to formation of cross-linked silica network structure in the membranes. The obtained membranes were found to have good thermal stability up to $260^{\circ} \mathrm{C}$, the methanol diffusion coefficients of all Si-sPS/A membranes were significantly lower meanwhile their selectivity was higher than those of Nafion ${ }^{\circledR} 117$ membrane. This is a significant advantage for membrane materials used for DMFCs.

The synthesis of proton conducting composite membranes from cross-linked poly(vinyl alcohol) and poly(styrene sulfonic acid)-functionalized silica nanoparticles (PSSA-Si) is described in [8]. Twostep cross-linking process involving sulfosuccinic acid (SSA) and glutaraldehyde as cross-linking agents was conducted to provide additional proton source and to enhance hydrolytic and mechanical stabilities. PSSA-Si were synthesized from vinyltrimethoxysilane via Stober method followed by radical polymerization of sodium 4-vinylbensene sulfonate. Proton conductivities of these composite membranes were found to increase with PSSA loading and PSSA content. Promising proton conductivities of 0.072 $\mathrm{S} / \mathrm{cm}$ were obtained from PVA-8\%PSSA-Si-10 and PVA-12\%PSSA-Si-10 membranes.

The aim of this work is to develop a new approach to obtain cross-linked proto organicinorganic materials on the base of acrylic monomers and silica precursors. The characterization of the synthesized materials was conducted to estimate their potential as proton conductive membranes in fuel cell application.

\section{Experimental}

All reagents used (acrylonitrile (AN), acrylic acid (AA), 3-sulfopropyl acrylate potassium salt (SPAK), ethyleneglycole dimethacrylate (EGDMA), 3-methacryloxypropyltrimethoxysilane (MAPTMS)) were purchased from Sigma-Aldrich and used as received (Table 1).

The series of membranes were prepared by UV polymerization of acrylic monomers (at the presence of photoinitiator, 2,2-dimethoxy-2-phenylacetophenone (DMPA), $2.0 \mathrm{wt} . \%$ ) and simultaneous solgel transformation of MAPTMS-based sol-gel system. The feed compositions used for the preparation of hybrid organic-inorganic membranes are summarized in Table 2. Ethylene glycol dimethacrylate (EGDMA) was used as a cross-linker. The polymeric parts of the membranes were prepared similar to the method described elsewhere [9]: aqueous solution of water-soluble reagents (AA, SPAK and EGDMA) was mixed with and appropriate amount of AN and DMPA for $35 \mathrm{~min}$ at $500 \mathrm{rpm}$. After that, sol-gel system of MAPTMS was added to polymerizing system and the resulting formulation was stirred for $30 \mathrm{~min}$ at $500 \mathrm{rpm}$. The formulations were placed into the glass mold $(50 \mathrm{~mm} \times 20 \mathrm{~mm} \times 0.15 \mathrm{~mm})$ and UV-irradiated for $10 \mathrm{~min}$, then the obtained membranes were peeled from the glass substrate and washed by distilled water. Finally, membrane samples were dried in an oven at $50^{\circ} \mathrm{C}$ until constant weight.

To determine the content of gel-fraction in the synthesized membranes, they were extracted with methanol for 1 day in a Soxhlet extraction apparatus. Gel-fraction was determined using the following 
Names and structures of reagents

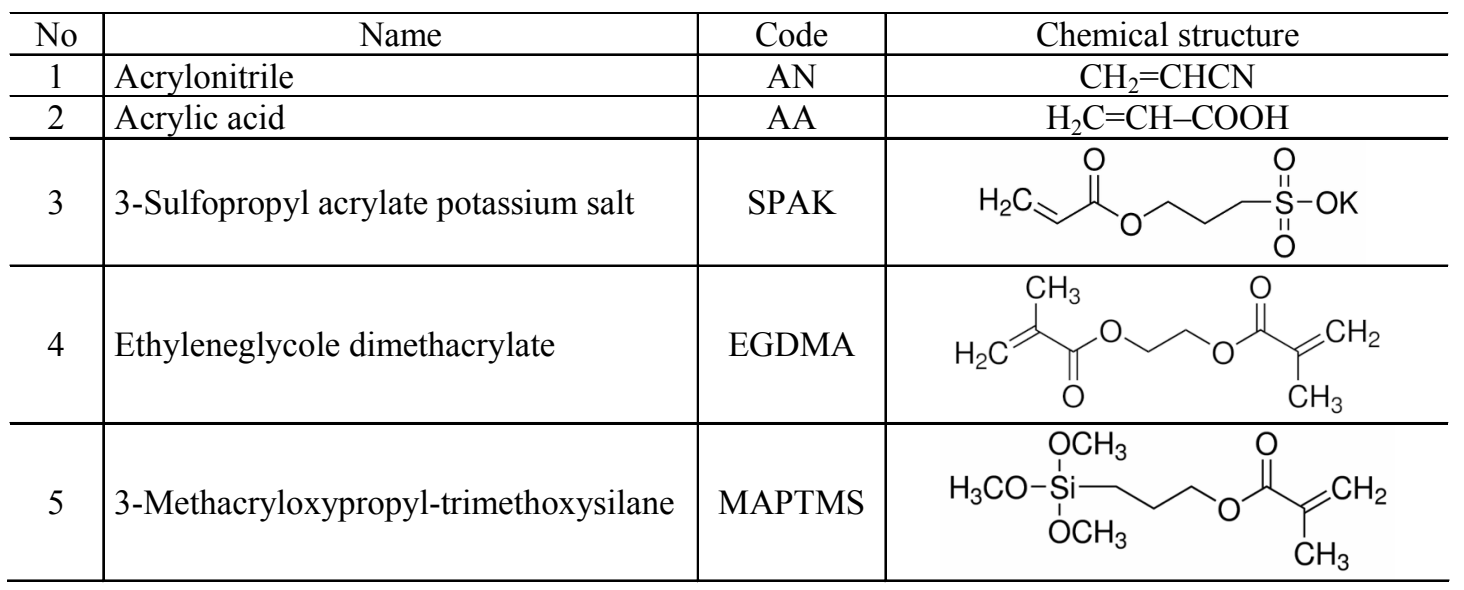

equation:

$\mathrm{G}=\left(\mathrm{m}_{\mathrm{ex}} / \mathrm{m}\right) \cdot 100 \%$,

where $\mathrm{m}_{\mathrm{ex}}$ and $\mathrm{m}$ are the sample masses after and before extraction, respectively.

Table 2

Feed compositions for membrane preparation

\begin{tabular}{c|c|c|c|c|c}
\hline Sample & $\begin{array}{c}\text { AN, } \\
\text { wt.\% }\end{array}$ & $\begin{array}{c}\text { AA, } \\
\text { wt.\% }\end{array}$ & $\begin{array}{c}\text { SPAK, } \\
\text { wt.\% }\end{array}$ & $\begin{array}{c}\text { EGDMA, } \\
\text { wt.\% }\end{array}$ & $\begin{array}{c}\text { MAPTMS } \\
\text { wt.\% }\end{array}$ \\
\hline S1 & 40 & 20 & 25 & 15 & - \\
\hline S2 & 40 & 20 & 25 & 15 & 3 \\
\hline S3 & 40 & 20 & 25 & 15 & 5 \\
\hline S4 & 40 & 20 & 25 & 15 & 7 \\
\hline S5 & 40 & 20 & 25 & 15 & 10 \\
\hline
\end{tabular}

Proton conductivity measurements were conducted using impedance spectroscopy (AUTOLAB impedance spectrometer (EcoChem, the Netherlands) with FRA software equipped by thermostat). Before measurements, the samples were immersed in $0.1 \mathrm{M} \mathrm{HCl}$ at room temperature to convert the membranes to $\mathrm{H}^{+}$ionic form. The samples were placed between two Pt electrodes followed by an application of voltage in a frequency range of $10-10^{5} \mathrm{~Hz}$. Resistance values $(\mathrm{R})$ were taken at the minimum imaginary response in the Nyquist plot (Z'vs. Z'). The membrane conductivity was calculated from the membrane resistance using the following expression:

$\sigma=l / \mathrm{RS}$,

where $\sigma$ is the proton conductivity, $\mathrm{S} \mathrm{cm}^{-1} ; l$ is the membrane thickness, $\mathrm{cm}$; $\mathrm{S}$ is the cross-sectional area of the sample, $\mathrm{cm}^{2}$.

The ion-exchange capacity (IEC) value of the synthesized membranes was measured by the classic titration technique. First, the membranes were placed into $0.1 \mathrm{M} \mathrm{HCl}$, washed with distilled water, and then converted to sodium form by immersing the membranes in $2.0 \mathrm{M} \mathrm{NaCl}$ for $24 \mathrm{~h}$ to complete a substitution of sulfogroups' protons with sodium ions. The released protons were titrated by $0.004 \mathrm{M} \mathrm{NaOH}$ solution. The IEC value was calculated as a number of mg-equiv. of sulfogroups per $1 \mathrm{~g}$ of dry polymer from the equation:

IEC $=\mathrm{C}_{(\mathrm{NaOH})} \cdot \mathrm{V}_{(\mathrm{NaOH})} /$ weight (polymer),

where $\mathrm{C}$ is the concentration of $\mathrm{NaOH}$ solution (M) and $\mathrm{V}$ is the volume of $\mathrm{NaOH}$ consumed $(\mathrm{mL})$.

Thermogravimetric and differential thermal analyses of the samples of polymer and polymersilica membranes were performed using Derivatograph Q-1500D (Paulik-Paulik-Erdey) within the temperature range of $20-600^{\circ} \mathrm{C}$ at a heating rate of $5^{0} \mathrm{C} \mathrm{min}^{-1}$. Alumina was used as a standard. The samples weight was $300 \mathrm{mg}$.

Oxidative stability of the prepared membranes was examined by immersing them in Fenton reagent (3\% aqueous solution containing $2 \mathrm{ppm} \mathrm{FeSO}_{4}$ ) at $60^{\circ} \mathrm{C}$. The degradation of membranes was evaluated by measuring weight loss and visual observation.

\section{Results and discussion}

A series of polyacrylate silica-containing membranes were synthesized via in situ polymerization method as a result of simultaneous formation of organic and inorganic networks (Fig. 1).

The choice of acrylic monomers for polymer membranes and polymer matrix of organic-inorganic membranes allows applying UV technique for their 


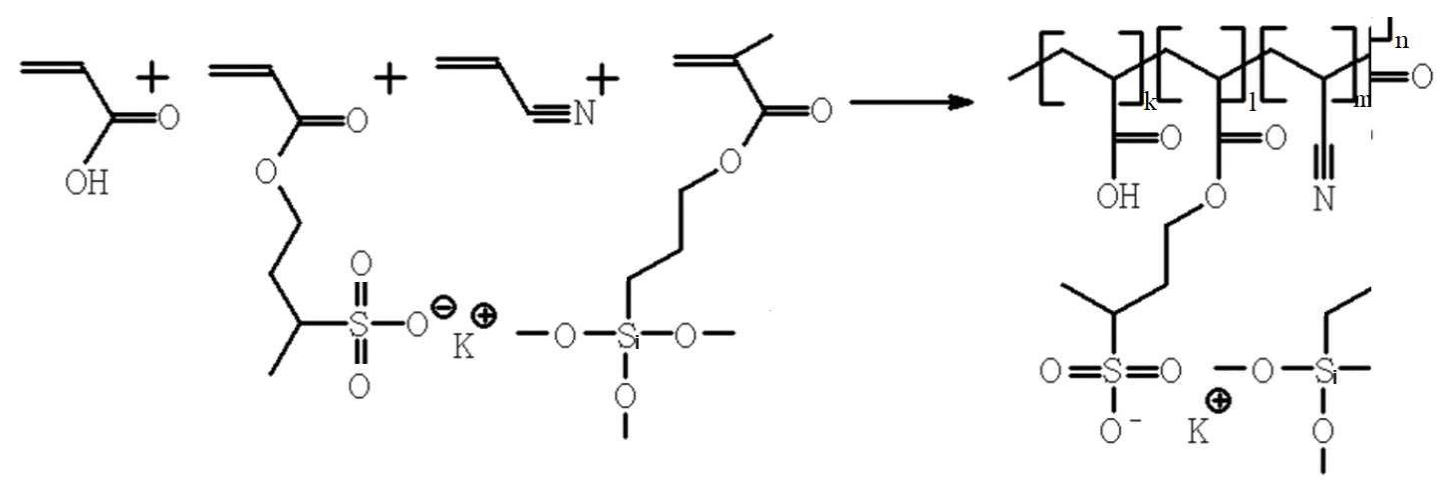

Fig. 1. Scheme of polymerization process

curing, which is a high-speed and suitable method of polymerization. The use of both hydrophilic and partially water-soluble monomers provides desired properties of the membranes. The role of acrylonitrile is to maintain the structural and mechanical stability and limit swelling ability of the membranes, whereas hydrophilic monomers (AA, SPAK) are introduced to ensure proton conductivity and retain water. Incorporation of $\mathrm{Si}(\mathrm{OR})_{3}$ groups of MAPTMS into polymer matrix offers two functions: first, siliconcontaining polymers present high thermal and chemical stability; and second, the hydrolysis and condensation reactions of $\mathrm{Si}(\mathrm{OR})_{3}$ groups lead to a self-crosslinked silica network in membranes [10].

As a result of in situ polymerization, we obtain elastic thin films with the thickness of ca. $150 \mathrm{~mm}$. Transparency of the obtained films is the evidence of homogeneity of their morphology. Gel-fraction yields were high (for the samples S1, S2, S3, S4 and S5 gel-fraction yields were 98.7, 99.6, 99.7, 98.6 and 97.9 wt.\%, respectively), confirming that photoinitiated polymerization passed till high conversion and the cross-linked composite structure was formed.

Proton conductivity is the most essential characteristic determining the efficiency of material use as proton conductive membrane in fuel cell. Proton diffusion through membrane can be described by the Grotthus mechanism [11]. It was found that proton conductivity of membranes depended on their composition and temperature. Temperature dependence of real and imaginary resistance values of the membrane S1 is presented in Fig. 2.

Proton conductivities of the samples were measured from these plots and the data are summarized in Table 3. For all samples, one can observe the positive temperature-conductivity dependence that suggests a thermally activated process. Obviously, elevating temperature increased structural reorientation, water uptake and mobility of water and protons facilitating proton transport and hence contributed to the improvement of proton

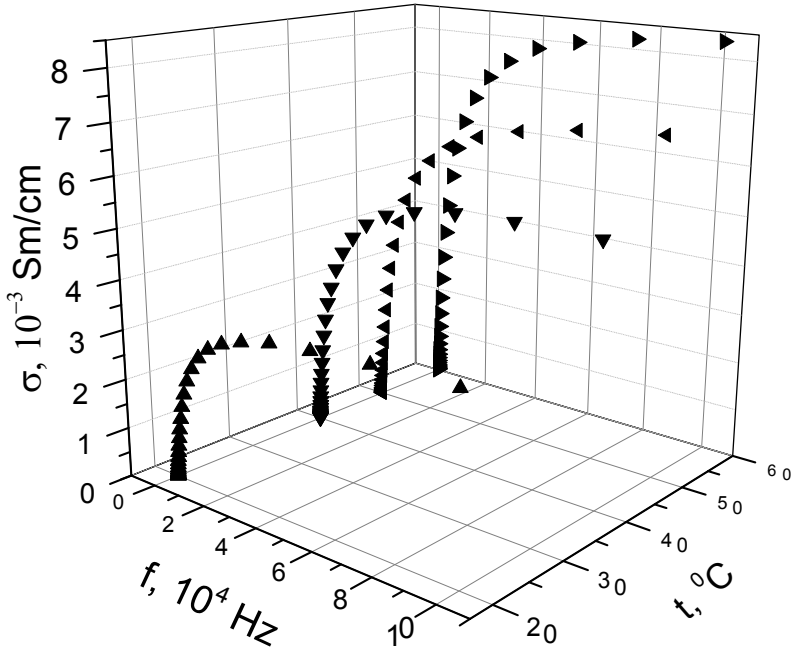

Fig. 2. Temperature dependence of proton conductivity of membrane $\mathrm{S} 1$

conductivity.

Table 3

Proton conductivity of membranes at different temperatures

\begin{tabular}{c|c|c|c|c|c}
\hline \multirow{2}{*}{$\mathrm{t},{ }^{0} \mathrm{C}$} & \multicolumn{5}{|c}{$\sigma \cdot 10^{-3}, \mathrm{~S} \mathrm{~cm}$} \\
\cline { 2 - 6 } & $\mathrm{S} 1$ & $\mathrm{~S} 2$ & $\mathrm{~S} 3$ & $\mathrm{~S} 4$ & $\mathrm{~S} 5$ \\
\hline 20 & 0.9 & 5.1 & 6.3 & 4.9 & 3.8 \\
\hline 40 & 1.5 & 7.6 & 9.8 & 7.5 & 5.2 \\
\hline 50 & 2.3 & 9.7 & 10.2 & 8.7 & 7.6 \\
\hline 60 & 3.0 & 10.6 & 11.2 & 10.0 & 9.4 \\
\hline
\end{tabular}

The proton conductivities of the synthesized membranes were found to be promising: $10^{-4}-10^{-2}$ $\mathrm{S} \mathrm{cm}^{-1}$. The proton conductivity of the sample $\mathrm{S} 3$ at $60^{\circ} \mathrm{C}\left(1.12 \cdot 10^{-2} \mathrm{~S} \mathrm{~cm}^{-1}\right)$ was comparable to that of Nafion-117 $\left(1.52 \cdot 10^{-2} \mathrm{~S} \mathrm{~cm}^{-1}\right)$.

Proton conductivities of the synthesized membranes $v s$. MAPTMS weight fraction were also determined and are shown in Fig. 3,a.

Considering the effect of the added MAPTMS 


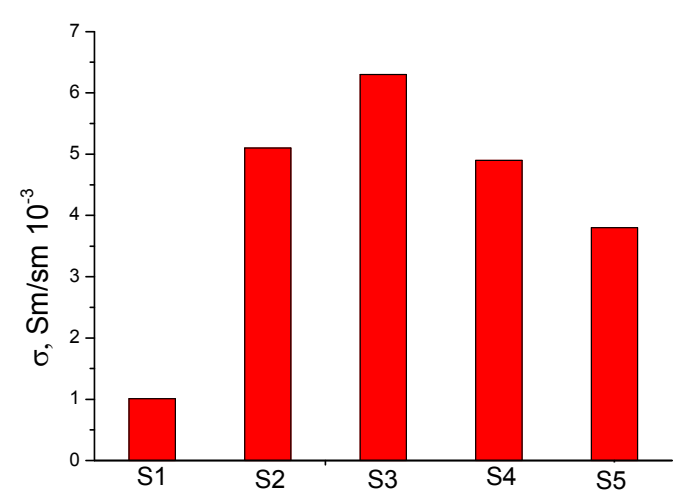

a

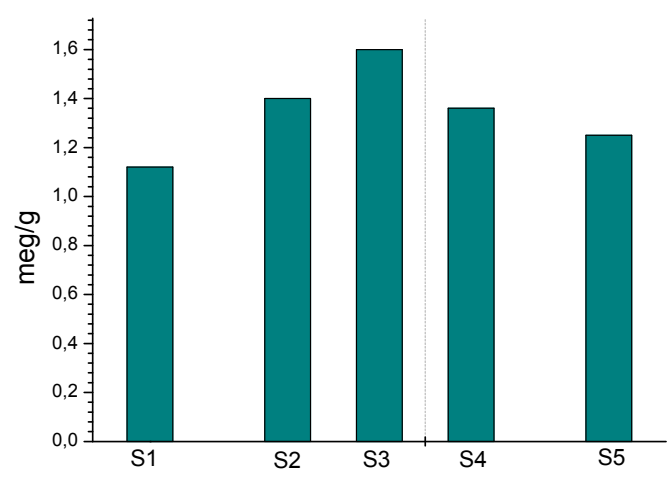

Fig. 3. Transport properties of membranes as a function of MAPTMS content: a - proton conductivity; $b$ - IEC

content on proton conductivity, nanocomposite membranes with larger added MAPTMS content (up to $5 \mathrm{wt} . \%)$ provide higher proton conductivity. The enhancement in proton conductivity of the sample S2 compared to that of the sample S1 is almost 6fold. At the same time, a further increase in inorganic part content leads to some decrease in proton conductivity. These results correlate with the results obtained by Yaroslavtsev et al. [12]. They explained the changes in proton conductivity of hybrid membranes by the influence of the dopant on the ion transport in the channels. The introduction of nanoparticles is accompanied by widening of pores and corresponding enlargement of channels connecting them. Since it is the channels that govern the membrane conductivity, the proton conductivity increases. The decrease in proton conductivity at higher nanoparticle concentration was explained by a decrease in pore space as a result of filling of the channels by nanoparticles.

Dzyazko et al. [13] for the first time revealed experimentally the influence of inorganic component on the porous structure of hybrid organic-inorganic composites synthesized by modification of strongly acidic gel-like cation-exchange resin with zirconium hydrophosphate using scanning and transmission electron microscopy and standard contact porosimetry. The inorganic component was found to exist in the form of non-aggregated globular nanoparticles and their aggregates. The aggregates are located in the voids of gel fields and stretch the polymer, while single nanoparticles are deposited in clusters as well as in macropores. As a result, the contribution of transport pores of the polymer to total porosity decreases. The authors also showed that the mobility of ions depends on the content of bonded, boundary and free water that is on the size of clusters. Bonded water occupies pores with a radius of $1.5 \mathrm{~nm}$, larger pores are filled with bonded and boundary or bonded, boundary and free water. The porosity caused by pores which contain only bonded water increases. Hence, transport properties of membrane are determined by the volume and size of both clusters and channels.

It is known that proton conductivity increases with increasing IEC and water uptake. It is because protons are transferred along ionic clusters consisting of polar groups such as $-\mathrm{SO}_{3} \mathrm{H}$ and the number of ionic clusters is related to the number of $-\mathrm{SO}_{3} \mathrm{H}$ groups and water content in the membrane. More inorganic component and, accordingly, water absorption make protons more mobile, therefore IEC of membranes is significantly improved.

As one can see, the experimental values of IEC of the investigated membranes range from 1.12 to $1.68 \mathrm{meq} \mathrm{g}^{-1}$, and it was also worth mentioning that they are higher than that of Nafion 117 membrane. Interestingly, that IEC of the samples S2 and S3 gradually increased compared to the sample $\mathrm{S} 1$, whereas we observed decrease in the values of IEC (Fig. 3,b) at MAPTMS content above 5 wt.\%, which coincides with decrease in proton conductivity of the same membranes (Table 3 and Fig. 3,a).

The oxidative stability of the prepared organicinorganic membranes in Fenton reagent was recognized as an important indication of the durability of membranes in fuel cells. During fuel cell operation possible degradation of the polymer electrolyte is caused by oxygen diffusing through the membrane and undergoing incomplete reduction at the anode to form $\mathrm{HO}$ and $\mathrm{HO}_{2}$ radicals [14]. When active radicals contact with membrane, the irreversible degradation can occur.

Two phenomena are in competition during immersion of the material in oxidizing solutions. First, polymer chain is degraded leading to a weight decrease, and in parallel the cross-links may be cleaved leading to a decrease in cross-linking density 
and a subsequent increase in the swelling of the material [15]. Thus, an initial weight increase followed by a weight decrease may be observed (Fig. 4).

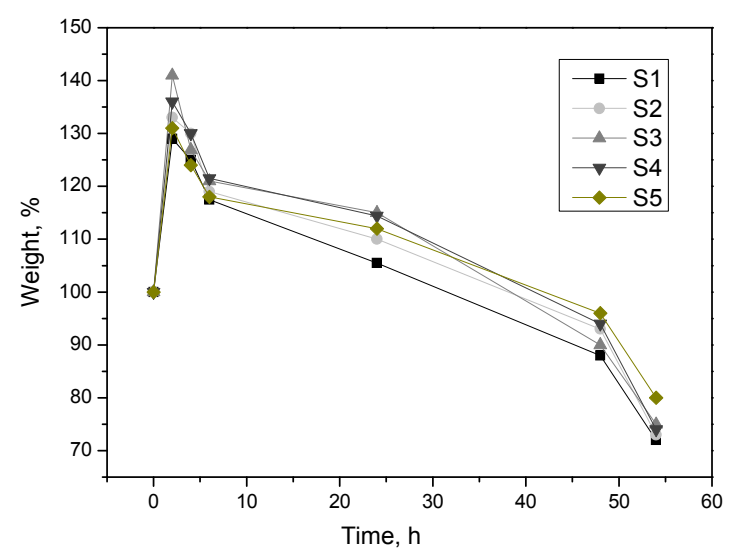

Fig. 4. Oxidative stability of the membranes

Silica improves oxidative stability due to its cross-linking effect, which renders the membrane more compact. It should be mentioned that none of the investigated membranes were broken into small

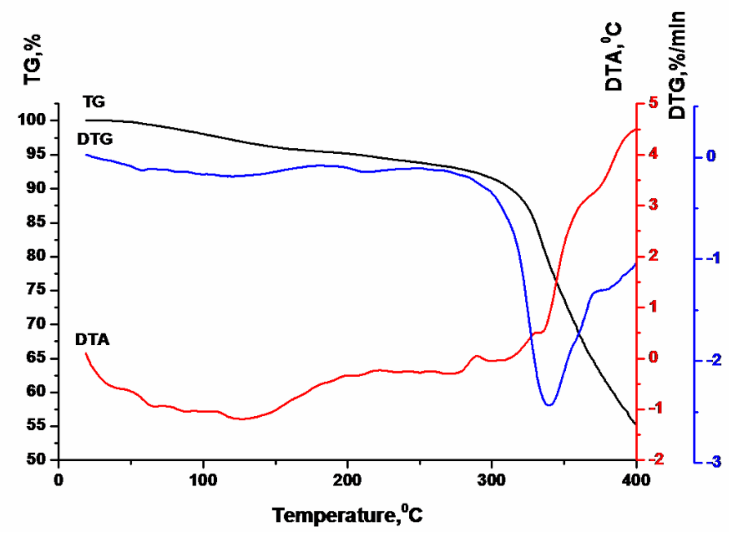

a

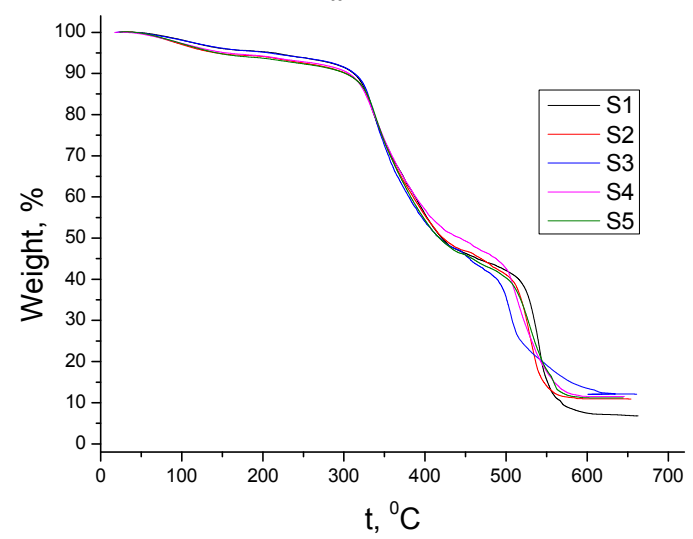

c pieces, all of the samples remained in a good form after the testing period.

To evaluate the thermal stability of polymer and organic-inorganic membranes, complex thermogravimetric and differential thermal analysis of samples was conducted. The TGA curves of the membranes are shown in Fig. 5.

All the membranes exhibited degradation curve with several steps. The weight losses of the samples, observed in the temperature range of $20-190^{\circ} \mathrm{C}$, may be attributed to evaporation of physically absorbed and chemically bound water. The weight loss occurring at the temperature interval of $190-350^{\circ} \mathrm{C}$ was attributed to the splitting-off of sulfonic acid groups, and weight losses at this temperature range increased with the rise of IEC. Above $350^{\circ} \mathrm{C}$, the membranes underwent the degradation step, which corresponded to the decomposition of the main chain and crosslinking bridges.

The inspections of the thermograms suggested that polymer and organic-inorganic membranes had good thermal stability, which could be explained as follows. First, the $\mathrm{Si}-\mathrm{O}$ bond energy was higher than that of $\mathrm{C}-\mathrm{C}$ bond. Second, the hydrolysis and

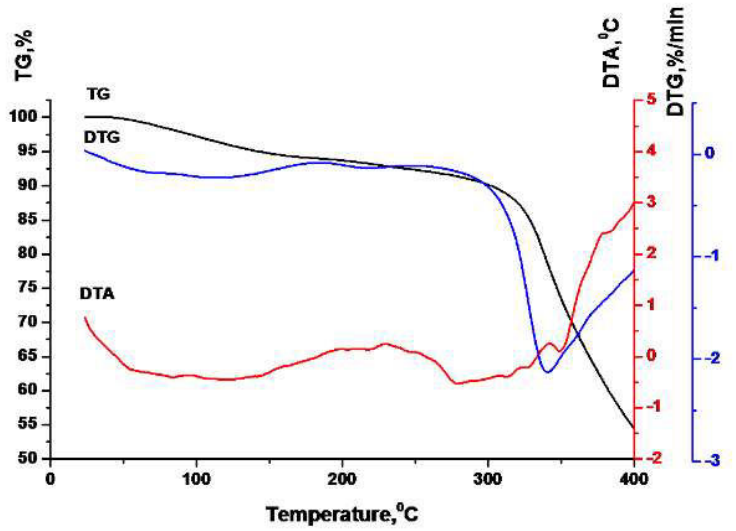

b

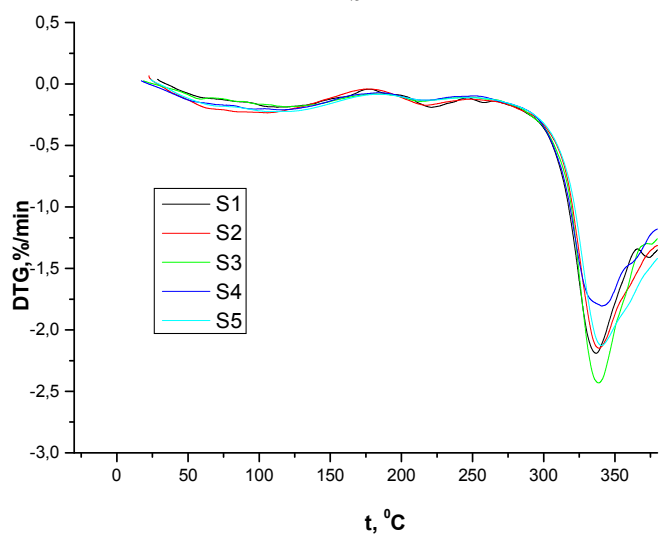

d

Fig. 5. Derivatograms of the samples: a) TG, DTG and DTA curves for the sample S1; b) TG, DTG and DTA curves for the sample S5; c) TG curves for the samples S1-S5; d) DTG curves for the samples S1-S5 
condensation reactions of $\mathrm{Si}(\mathrm{OR})_{3}$ groups in membrane led to the formation of cross-linked silica network structure which made the membrane more compact and hence improved the thermal stability. So, the temperature of the beginning of sulfo-group decomposition for the polymer membrane S1 was $336.8^{\circ} \mathrm{C}$ whereas it was $340.8^{\circ} \mathrm{C}$ for $\mathrm{S} 5$. The temperature of the beginning of the membrane matrix thermooxidation increased from $513^{\circ} \mathrm{C}$ for $\mathrm{S} 1$ till $528^{\circ} \mathrm{C}$ for S5.

\section{Conclusions}

Cross-linked sulfo-containing polyacrylate and silica-polyacrylate membranes were successfully synthesized via convenient method, polymerization in situ. Their suitability as PEMs for DMFC was investigated by impedance spectroscopy, thermogravimetric analysis and determining IEC. The synthesized membranes were found to have good thermal stability, oxidative stability, high proton conductivity and IEC. Based on these results, it could be concluded that the membranes had good potential as PEMs for DMFC.

\section{REFERENCES}

1. Stephan A.M., Nahm K.S. Review on composite polymer electrolytes for lithium batteries // Polymer. - 2006. - Vol.47. P.5952-5964.

2. Fuel cells. Ullmann's Encyclopedia of Industrial Chemistry / Cappadonia M., Stimming U., Kordesch K., Oliveira J.C. - John Wiley \& Sons, Inc., 2000.

3. Larminie J. Fuel cells. Kirk-Othmer Encyclopedia of Chemical Technology. - John Wiley \& Sons, Inc., 2002.

4. Membranes for direct methanol fuel cell applications: Analysis based on characterization, experimentation and modeling / Silva V.S., Mendes A.M., Madeira L.M., Nunes S.P. // Adv. Fuel Cell. - 2005. - P.1-24.

5. Smitha B., Sridhar S., Khan A.A. Polyelectrolyte complexes of chitosan and poly(acrylic acid) as proton exchange membranes for fuel cells // Macromolecules. - 2004. - Vol.37. - P.2233-2239.

6. Improved performance using tungsten carbide/carbon nanofiber based anode catalysts for alkaline direct ethanol fuel cells / Oh Y., Kim S.K., Peck D.H., Jang J.S., Kim J., Jung D.H. // Int. J. Hydrogen Energy. - 2014. - Vol.39. - P.15907-15912.

7. Zhong S., Cui X., Dou S., Liu W. Preparation and characterization of self-crosslinked organic/inorganic proton exchange membranes // J. Power Sources. - 2010, vol. 195, pp. 3990-3995.

8. Proton conducting composite membranes from crosslinked poly(vinyl alcohol) and poly(styrene sulfonic acid)functionalized silica nanoparticles / Kamjornsupamitr T., Sangthumchai T., Youngme S., Martwiset S. // Int. J. Hydrogen
Energy. - 2018. - Vol.43. - P.11190-11201.

9. The influence of the hydrophobic component content on the properties of hybrid polymer-inorganic membranes / Demydova Kh., Horechyy A., Yevchuk I., Demchyna O. // Chem. Chem. Technol. - 2018. - Vol.12. - P.58-63.

10. Кио P.-L., Chen W.-F., Liang W.-J. Proton transportation in an organic-inorganic hybrid polymer electrolyte based on a polysiloxane/poly(allylamine) network // J. Polym. Sci. Part A: Polym. Chem. - 2005. - Vol.43. - P.3359-3367.

11. Yaroslavtsev A.B., Nikonenko V.V., Zabolotsky V.I. Ion transfer in ion-exchange and membrane materials // Russ. Chem. Rev. - 2003. - Vol.72. - P.393-421.

12. Nanostructured materials for low-temperature fuel cells / Yaroslavtsev A.B., Dobrovolsky Yu.A., Shaglaeva N.S., Frolova L.A., Gerasimova E.V., Sanginov E.A. // Russ. Chem. Rev. - 2012. Vol.81. - P.191-220.

13. Polymer ion-exchangers modified with zirconium hydrophosphate for removal of $\mathrm{Cd}^{2+}$ ions from diluted solutions / Dzyazko Yu.S., Ponomaryova L.N., Volfkovich Yu.M., Sosenkin V.E., Belyakov V.N. // Sep. Sci. Technol. - 2013. Vol.48. - P.2140-2149.

14. Hubner G. Roduner E. EPR investigation of $\mathrm{HO} /$ radical initiated degradation reactions of sulfonated aromatics as model compounds for fuel cell proton conducting membranes // J. Mater. Chem. - 1999. - Vol.9. - P.409-418.

15. Chikh L., Delhorbe V., Fichet O. (Semi-)interpenetrating polymer networks as fuel cell membranes // J. Membr. Sci. 2011. - Vol.368. - P.1-17.

Received 30.01.2019

\section{ОДЕРЖАННЯ І ДОСЛІДЖЕННЯ ВЛАСТИВОСТЕЙ ЗШИТИХ МЕТОДОМ УФ-ОПРОМІНЕННЯ ОРГАНО- НЕОРГАНІЧНИХ МЕМБРАН}

\section{М.М. Жигайло, О.І. Демчина, І.Ю. Евчук, Б.І. Рачій, B.В. Кочубей}

Синтезовано серію гібридних полімер-неорганічних мембран на основі акрилових мономерів (акрилової кислоти, акрилонітрилу та калієвої солі 3-сульфопропілакрилату) та зольгель системи 3-метакрилоксипропілтриметоксисилан-етанолвода з різним співвідношенням органічного та неорганічного компонентів. Метод синтезу - УФ-ініційована полімеризація мономерів у присутності фотоініціатора та зиивача та зольгель процес іп situ. Високий вміст гель-фракиії (>95\%) свідчить про успішний синтез $i$ одержання зиитих полімер-неорганічних структур, нерозчинних в органічних розчинниках $i$ водi. Дослідження методом імпедансної спектроскопії встановили високу протонну провідність мембран $\left(10^{-4}-10^{-2} \mathrm{CM} / \mathrm{cm}\right)$ та їі залежність від температури та складу матеріалу. Дані мембрани характеризуються відносно доброю хімічною стабільністю в часовому інтервалі вимірювань і високою іонообмінною ємністю $(1,12-1,68$ мекв/2). Термогравіметричні дослідження засвідчили вплив неорганічної складової на підвищення термічної стабільності мембран. Отже, синтезовані органо-неорганічні матеріали за сумою характеристик можуть бути застосовані як протонопровідні мембрани у метанольних паливних комірках. 
Ключові слова: протонопровідна мембрана, органонеорганічний матеріал, УФ-тверднення, золь-гель процес, акрилова кислота, акрилонітрил, калієва сіль 3-сульфопропілакрилату, 3-метакрилоксипропілтриметоксисилан.

\section{PREPARATION AND CHARACTERIZATION OF UV- CURABLE CROSS-LINKED ORGANIC-INORGANIC MEMBRANES}

M.M. Zhyhailo a, O.I. Demchyna ${ }^{a, ~}$, I.Yu. Yevchuka, B.I. Rachiy ${ }^{b}$, V.V. Kochubey ${ }^{c}$

a Department of Physical Chemistry of Fossil Fuels of the L.M. Lytvynenko Institute of Physical-Organic Chemistry and Coal Chemistry of the National Academy of Sciences of Ukraine, Lviv, Ukraine

b Vasyl Stefanyk Precarpathian National University, IvanoFrankivsk, Ukraine

c Lviv Polytechnic National University, Lviv, Ukraine

* e-mail: demchynaoksana@ukr.net

The synthesis of a series of hybrid polymer-inorganic membranes based on acrylic monomers (acrylic acid, acrylonitrile and 3-sulfopropylacrylate potassium salt) and sol-gel system 3methacryloxypropyltrimethoxysilane-ethanol-water with various ratios organic/inorganic is reported in this paper. The synthetic procedure includes $U V$-initiated polymerization of monomers in the presence of photoinitiator and cross-linker and sol-gel process in situ. A high content of gel fraction (>95\%) indicates the successful synthesis and formation of cross-linked polymer-inorganic structures insoluble in organic solvents and water. Investigations performed by means of impedance spectroscopy showed high proton conductivity of membranes $\left(10^{-4}-10^{-2} \mathrm{~S} \mathrm{~cm}^{-1}\right)$ and its dependence on temperature and material composition. The prepared membranes have relatively good chemical stability in the time interval of testing and high ionexchange capacity $\left(1.12-1.68 \mathrm{meq}^{-1}\right)$. Thermogravimetric study showed the influence of the content of inorganic component on the increase of thermal stability of the membranes. Consequently, taking into account the complex of the characteristics, the synthesized organic-inorganic materials is a potential candidate for DMFC application.

Keywords: proton conductive membrane; organic-inorganic material; UV curing; sol-gel process; acrylic acid; acrylonitrile; 3-sulfopropylacrylate potassium salt; 3-methacryloxypropyltrimethoxysilane.

\section{REFERENCES}

1. Stephan A.M., Nahm K.S. Review on composite polymer electrolytes for lithium batteries. Polymer, 2006, vol. 47, pp. 59525964.

2. Cappadonia M., Stimming U., Kordesch K., Oliveira J.C., Fuel cells. Ullmann's Encyclopedia of Industrial Chemistry, John Wiley \& Sons, Inc., 2000.

3. Larminie J., Fuel cells. Kirk-Othmer Encyclopedia of Chemical Technology, John Wiley \& Sons, Inc., 2002.

4. Silva V.S., Mendes A.M., Madeira L.M., Nunes S.P. Membranes for direct methanol fuel cell applications: analysis based on characterization, experimentation and modeling. In: Advances in Fuel Cells, 2005.
5. Smitha B., Sridhar S., Khan A.A. Polyelectrolyte complexes of chitosan and poly(acrylic acid) as proton exchange membranes for fuel cells. Macromolecules, 2004, vol. 37, pp. 22332239.

6. Oh Y., Kim S.-K., Peck D.-H., Jang J.-S., Kim J., Jung D.-H. Improved performance using tungsten carbide/carbon nanofiber based anode catalysts for alkaline direct ethanol fuel cells. International Journal of Hydrogen Energy, 2014, vol. 39, pp. 15907-15912.

7. Zhong S., Cui X., Dou S., Liu W. Preparation and characterization of self-crosslinked organic/inorganic proton exchange membranes. Journal of Power Sources, 2010, vol. 195, pp. 3990-3995.

8. Kamjornsupamitr T., Sangthumchai T., Youngme S., Martwiset S. Proton conducting composite membranes from crosslinked poly(vinyl alcohol) and poly(styrene sulfonic acid)functionalized silica nanoparticles. International Journal of Hydrogen Energy, 2018, vol. 43, pp. 11190-11201.

9. Demydova Kh., Horechyy A., Yevchuk I., Demchyna $\mathrm{O}$. The influence of the hydrophobic component content on the properties of hybrid polymer-inorganic membranes. Chemistry \& Chemical Technology, 2018, vol. 12, pp. 58-63.

10. Kuo P.-L., Chen W.-F., Liang W.-J. Proton transportation in an organic-inorganic hybrid polymer electrolyte based on a polysiloxane/poly(allylamine) network. Journal of Polymer Science, Part A: Polymer Chemistry, 2005, vol. 43, pp. 3359-3367.

11. Yaroslavtsev A.B., Nikonenko V.V., Zabolotsky V.I. Ion transfer in ion-exchange and membrane materials. Russian Chemical Reviews, 2003, vol. 72, pp. 393-421.

12. Yaroslavtsev A.B., Dobrovolsky Yu.A., Shaglaeva N.S., Frolova L.A., Gerasimova E.V., Sanginov E.A. Nanostructured materials for low-temperature fuel cells. Russian Chemical Reviews, 2012, vol. 81 pp. 191-220.

13. Dzyazko Yu.S., Ponomaryova L.N., Volfkovich Yu.M., Sosenkin V.E., Belyakov V.N. Polymer ion-exchangers modified with zirconium hydrophosphate for removal of $\mathrm{Cd}^{2+}$ ions from diluted solutions. Separation Science and Technology, 2013, vol. 48 , pp. $2140-2149$.

14. Hubner G. Roduner E. EPR investigation of HO/ radical initiated degradation reactions of sulfonated aromatics as model compounds for fuel cell proton conducting membranes. Journal of Material Chemistry, 1999, vol. 9, pp. 409-418.

15. Chikh L., Delhorbe V., Fichet O. (Semi-)interpenetrating polymer networks as fuel cell membranes. Journal of Membrane Science, 2011, vol. 368, pp. 1-17. 